\title{
高分子電解質のスケール析出抑制能に对する 分子量および化学組成の影響122)
}

\author{
(1987 年 2 月 20 日受理) \\ 同本俊*・林史 郎**
}

高分子電解質として, 化学組成が同一で分子量が 600〜25000のポリアクリル酸ナトリウム ( 9 種類), および分子量が 3000 で種々の組成をもつアクリル酸ナトリウム・2-ヒドロキシ-3-アリルオキシ-1-プ ロハンンスホン酸ナトリウムコポリマー(5 種類) とアクリル酸ナトリウム・3-フリルオキシ-1, 2-プロ

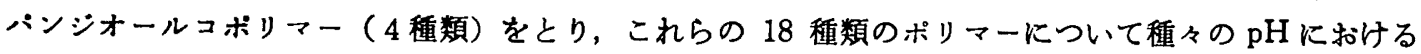
岸酸カルシウム析出抑制能を調べた結果，少数の高分子電解質を用い，単一の $\mathrm{pH}$ で推論した前報の析 出抑制機棈の正当性を再確認することができた。すなわち，析出抑制能はポリマーのキレート化能の增 大につれて大きくなるが，これがあまり大きくなるとゲル化が起こって有効濃度が低下し，㧕制能はか えって小さくなってしま5。溶液の $\mathrm{pH}$ を增大すると, 炎酸カルシウムの過飽和度が高くなるので, 析 出防止のためにはある程度ポリマーのキレートカおよび湿度を增大する必要がある。ポリマーのゲル化 は $\mathrm{COO}^{-}$基に $\mathrm{Ca}^{2+}$ イオンが吸着してゼ口荷電錯体を生じ，これが凝集またはミセル化するためであ ることを明らかにした。

\section{1 㒂西}

高分子電解面（以下，简笚のため「ポリマー」と略記する） は、水中における炭酸カルシウムスケールの析出を㧕制する働き があり，期近，命却水，海水およびボイラーなどの水処理郕とし て用いられている。著者は前報2の研究において種々のポリマー に対し，その作用機凿を梌討した結果，ポリマーの峞酸カルシ

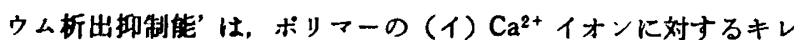
一トカととるに增大するが（口） $\mathrm{Ca}^{2+}$ イオン存在下に淤るる 'ダル化'によって城少すること、および（ハ）一般にキレートカ か增大するとがル化る起こりやすくなることを明らかにし（） ポリマーのキレートカおよびタル化しやすさが，いずれもポリマ 一の分子量扰よびカルボキシル基の量ととるに增大することを指 描している。

本研㠰では，ボリマーの分子量拈よび官能基の程数と組成を幅

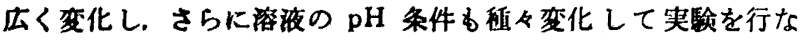
い，前報の推㻅が広く道用できるかどらか確かめよらとした。 た、゙ル化の機棤についてい梌討を加えた。

\section{2 实 梌}

(1) ボリマー料

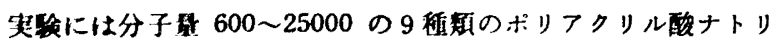

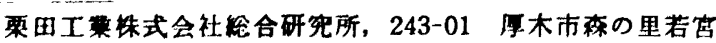

**现在要田工莱怢式会社研苋開発本部，160 東京都新宿区 西新宿

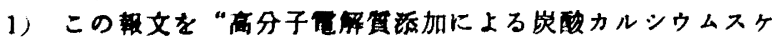
一ルの析出防止に时する研究（第 2 瓡）”とする.

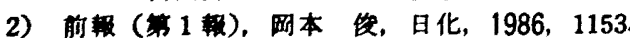

ウム (以下 PAA と略記する)，分子盟が 3000 で組成が異なる 5 種類のアクリル酸ナトリウム・2-ヒドロキシ-3-フリルオキシ-1フロパンルホン酸ナトリウムコポリマー（以下 AA·HAPS と 略記する)，扣よび分子量が 3000 で組成が異なる 4 程類のアクリ ル酸ナトリウム・3-フリルオキシ-1, 2-プロパンジオールコポリマ 一（以下 AA.APDO と略記する）を用いた。これらの 18 程類 のポリマーの組成扰よび分子量を表 1 に示す。このらち PAA-1, PAA-4，PAA-6，PAA-9 扣よび AA・HAPS-2 の 5 桖煩は前報2) の研究で用いたものと同一のものである（前報に护ける略号は本 報のものと異なるので表 1 に付した)。

(2) 析出抑制能

炭酸カルシウムの過蛀和溶液（陚駼液）にポリマーを加えて, $\mathrm{Ca}^{2+}$ イオン洪度 $\left[\mathrm{Ca}^{2+}\right]$ を测定し，岑酸カルシウムの析出を完全 に抑制するのに必要なポリマーの最小濃度 (Threshold Value, TV 値）を求めることにより判定した。試験は前報”の方法にし たがい，試験溶液の組成としては实際の開放循環冷却水系の標渒 的な水質に相当するものを用い， $\mathrm{pH}$ は 8.5.9.0 および 9.5 と した。

（3） キレート化能

$\mathrm{Ca}^{2+}$ イオンを含む水溶液（pH 8.5,9.0 および 9.5 $\left.5^{81}\right)$ そポリ

3）（2）の鹉娩では $\mathrm{HCl}$ および $\mathrm{NaOH}$ 溶液の派加により $\mathrm{pH}$ を调節したが，（3）斿よび（4）の試験ではつきのよ 5 飞悢海液を用いている。すなわち， $\mathrm{pH} 8.5$ の場合は $\mathrm{H}_{3} \mathrm{BO}_{3} 0.12 \mathrm{~mol}, \mathrm{Na}_{2} \mathrm{~B}_{4} \mathrm{O}_{7} \cdot 10 \mathrm{H}_{2} \mathrm{O} 0.02 \mathrm{~mol}, \mathrm{pH} 9.0$ の 场合仕 $\mathrm{H}_{3} \mathrm{BO}_{3} 0.06 \mathrm{~mol}, \mathrm{Na}_{2} \mathrm{~B}_{4} \mathrm{O}_{7} \cdot 10 \mathrm{H}_{2} \mathrm{O} 0.035 \mathrm{~mol}$, および $\mathrm{pH} 9.5$ の暏合は $\mathrm{H}_{3} \mathrm{BO}_{3} 0.02 \mathrm{~mol}, \mathrm{Na}_{2} \mathrm{~B}_{4} \mathrm{O}_{7} \cdot 10$ $\mathrm{H}_{2} \mathrm{O} 0.045 \mathrm{~mol}$, いずれも蒸留水に溶かして全を $1 \mathrm{dm}^{3}$ としたもの. 
Table 1 Composition of the polymers and their molecular weights

\begin{tabular}{|c|c|c|c|}
\hline No. & Code & Polymer composition $(\mathrm{mol} / \mathrm{mol})$ & $\begin{array}{l}\text { Molecular } \\
\text { weight }\end{array}$ \\
\hline 1. & $\mathrm{PAA}-1^{a)}$ & Sodium acrylate $=100$ & 600 \\
\hline 2. & PAA-2 & Sodium acrylate $=100$ & 1100 \\
\hline 3. & $\mathrm{PAA}-3$ & Sodium acrylate $=100$ & 1600 \\
\hline 4. & $\mathrm{PAA}-4^{(b)}$ & Sodium acrylate $=100$ & 3500 \\
\hline 5. & PAA-5 & Sodium acrylate $=100$ & 4000 \\
\hline 6. & PAA $\left.-6^{c}\right)$ & Sodium acrylate $=100$ & 4400 \\
\hline 7. & PAA-7 & Sodium acrylate $=100$ & 6000 \\
\hline 8. & PAA-8 & Sodium acrylate $=100$ & 13000 \\
\hline 9. & PAA-9d) & Sodium acrylate $=100$ & 25000 \\
\hline 10. & A A $\cdot$ HAPS -1 & Sodium acrylate/Sodium 2-hydroxy-3-allyloxy-1-propanesulfonate $=95 / 5$ & 3000 \\
\hline 11. & $\mathrm{AA} \cdot \mathrm{HAPS}-2^{e)}$ & Sodium acrylate/Sodium 2-hydroxy-3-allyloxy-1-propanesulfonate $=92 / 8$ & 3000 \\
\hline 12. & A A $\cdot$ H APS -3 & Sodium acrylate/Sodium 2 -hydroxy-3-allyloxy-1-propanesulfonate $=85 / 15$ & 3000 \\
\hline 13. & AA $\cdot$ HAPS -4 & Sodium acrylate/Sodium 2-hydroxy-3-allyloxy-1-propanesulfonate $=80 / 20$ & 3000 \\
\hline 14. & $A A \cdot H A P S-5$ & Sodium acrylate/Sodium 2-hydroxy-3-allyloxy-1-propanesulfonate $=75 / 25$ & 3000 \\
\hline 15. & $A A \cdot A P D O-1$ & Sodium acrylate $/ 3$-Allyloxy-1, 2 -propanediol $=95 / 5$ & 3000 \\
\hline 16. & $\mathrm{AA} \cdot \mathrm{APDO}-2$ & Sodium acrylate $/ 3-$ Allyloxy-1, 2 -propanediol $=92 / 8$ & 3000 \\
\hline 17. & $\mathrm{AA} \cdot \mathrm{APDO}-3$ & Sodium acrylate $/ 3-$ Allyloxy-1, 2 -propanediol $=80 / 20$ & 3000 \\
\hline 18. & $\mathrm{AA} \cdot \mathrm{APDO}-4$ & Sodium acrylate $/ 3$-Allyloxy-1, 2 -propanediol $=75 / 25$ & 3000 \\
\hline
\end{tabular}

Code expression in a previous paper ${ }^{2}$ is as follows : a) PAA-1, b) PAA-2, c) PAA-3, d) PAA-4, e) AA. HAPS.

マーを添加し，ポリマー1モルによってキレート化される Ca の モル数（キレート优, Chelating Value, CV 值)を测定すること により判定した。詳細は剪報2)に述へててある。

\section{(4) ゲル化しやすさ}

前報 ${ }^{29}$ の法により测定した。 $\mathrm{Ca}^{2+}$ イオンを含む水溶液（pH 8.5,9.0 扰よび 9.5) にポリマーを㳢加し，ゲル化の始まるポリ マーの取小添加浱度（ゲル化点, Gelation Point, GP 值)を求め た。また，本研究ではゲル化機棈を饸討するために，ポリマー湠 度を極端に大きくした場合のゲル化举秒括よび生成したゲルを槛

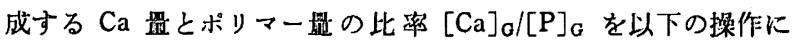
より湘定した。

蒸留水 $500 \mathrm{~cm}^{3}$ をコニカルビーカーにとり, $\mathrm{pH}$ が 8.5 となる ように（3）で用いた緩衙液を $10 \mathrm{~cm}^{3}$ 添加する。 $\mathrm{CaCl}_{2}$ 扰よび

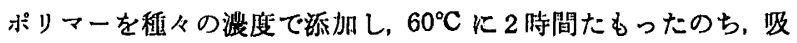
光度（濁度）を波長 $380 \mathrm{~nm}$ で测定する。生成したゲルを孔径 $0.1 \mu \mathrm{m}$ のメンブランフィルターで汇別, 蒸留水で洗浄したのち. $1 \times 10^{-2} \mathrm{~mol} \cdot \mathrm{dm}^{-3}$ の $\mathrm{HCl}$ 水溶液で溶解し, 溶液中の $\mathrm{Ca}^{2+}$ イオ

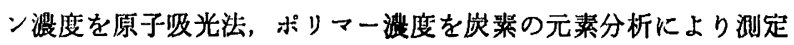
して求めた。

\section{3 結果と考案}

\subsection{PAA}

図 1 は租々の $\mathrm{pH}$ において，PAA の分子量と TV 值（岩酸

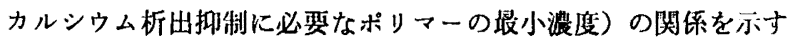

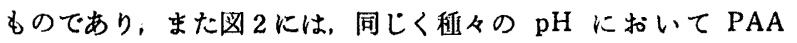
の分子量と $\mathrm{CV}$ 值 (ポリマー1モルあたりキレート化される $\mathrm{Ca}$ のモル数) および GP 值(ポリマーがゲル化し始めるポリマーの 最小浱度）の関係を示してある。

図1をみると，いずれの $\mathrm{pH}$ でも TV 值はある分子姑 $\left(10^{3}\right.$ 〜 104)のところで極小となり，その条件でポリマーの炭酸カルシウ ム析出抑例能が極大になることがわかる。しかし，同じ極小値で も $\mathrm{pH} 8.5$ に対するものはその値がさくく，分子量筈眀も広いの

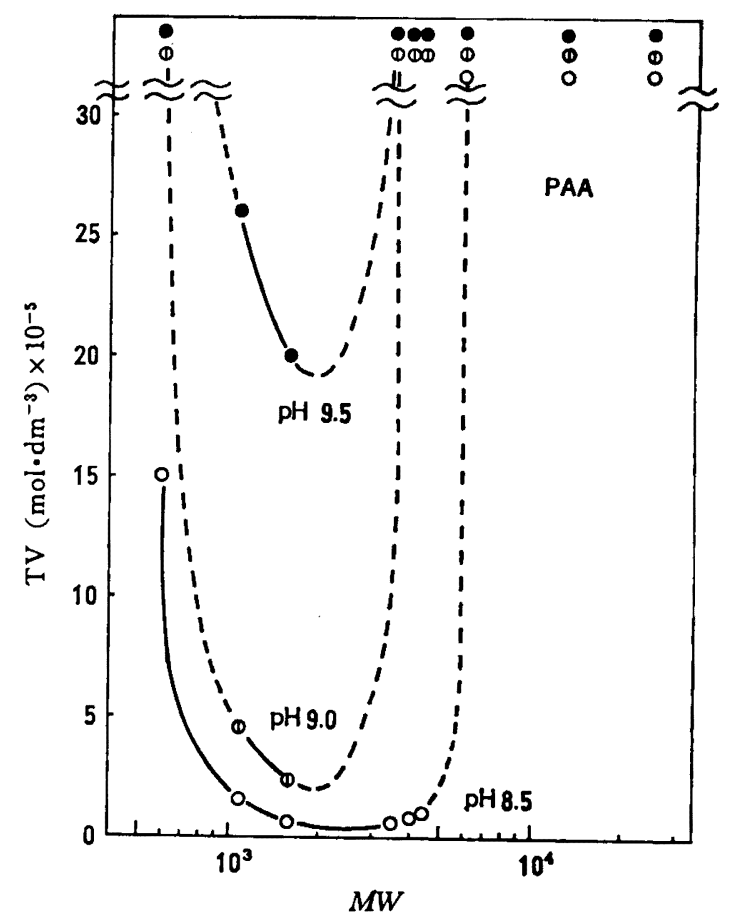

Fig. 1 Relationship between the molecular weight $(M W)$ and the threshold value (TV) for PAA

The initial concentrations of $\mathrm{Ca}^{2+}$ and $\mathrm{HCO}_{3}{ }^{-}$were $2.55 \times 10^{-8} \mathrm{~mol} \cdot \mathrm{dm}^{-8}$ and $5 \times 10^{-8} \mathrm{~mol} \cdot \mathrm{dm}^{-8}$

$\mathrm{PAA}$ was added at different concentrations and the solutions were kept at $60^{\circ} \mathrm{C}$ for $20 \mathrm{~h}$

でスケール防止には好㸝合である。 $\mathrm{pH}$ が上早するにつれて，TV

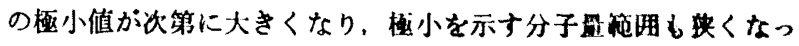
ているか，これは溶液の $\mathrm{pH}$ の增大につれて $\mathrm{HCO}_{2}^{-} \rightarrow \mathrm{CO}_{3}^{2-}$ $+\mathrm{H}^{+}$の解崔がすナみ $\mathrm{CO}_{3}^{2-}$ が增大するので, 苌被カルシウムい 


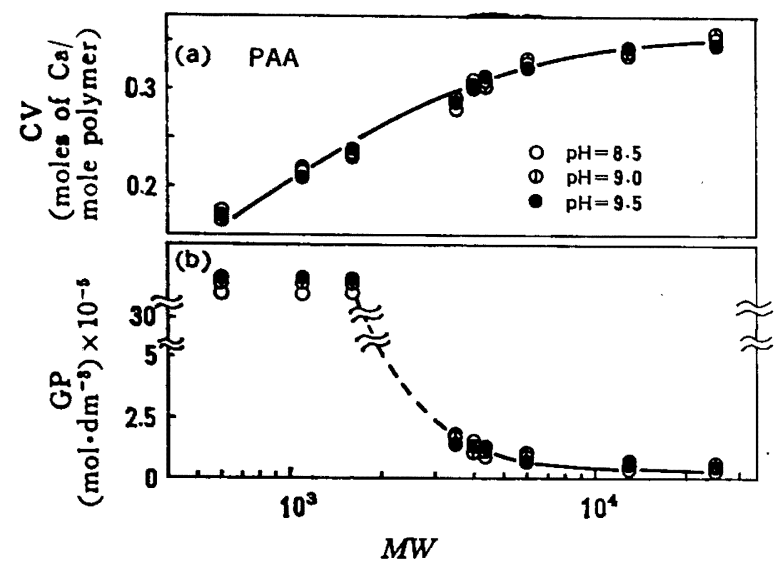

Fig. 2 Variations of the chelating value (CV) and gelation point (GP) with molecular weight $(M W)$ observed for PAA

CV ; The initial concentrations of $\mathrm{Ca}^{2+}$ and PAA were $5 \times 10^{-8} \mathrm{~mol} \cdot \mathrm{dm}^{-3}$ and $5 \times 10^{-8} \mathrm{~mol} \cdot \mathrm{dm}^{-3}$

The solutions were kept at $30^{\circ} \mathrm{C}$ for $20 \mathrm{~h}$

GP ; The initial $\mathrm{Ca}^{2+}$ concentration was $2.55 \times 10^{-3}$ $\mathrm{mol} \cdot \mathrm{dm}^{-\mathbf{s}}$

The solutions were kept at $60^{\circ} \mathrm{C}$ for $20 \mathrm{~h}$ after adding $\mathrm{PAA}$ at different concentrations

析出しやすさ（過鹐和度）が增加してゆくためである。炭酸か ルシウムの浴解度積 $\left(K_{\mathrm{8p}}=2.4 \times 10^{-9}, 60^{\circ} \mathrm{C}\right)$ から過飽和度 $\left[\mathrm{Ca}^{2+}\right]\left[\mathrm{CO}_{3}{ }^{2-}\right] / K_{\mathrm{Bp}}$ の值を求めると, $1.2 \times 10^{2}(\mathrm{pH} 8.5), 3.6 \times$

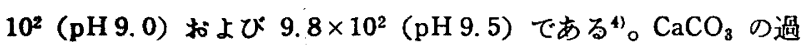
盷和度が高くなると，その析出を抑えるためにそれたけ多量の PAA の添加が必要になると考えるのであるが，現在のところ必 要添加量についての定量的な説明はできない。

図1の TV 曲線に極小が現われる理由は前報》に拈いて述べた とおりであり，图2の CV 曲線および GP 曲線をみれば明らか である。PAA の分子量が大きくなると，キレート化能は次第に 大きくなるが，ある分子量を越えるとゲル化が急に起こってくる ので PAA の有效渡度が低下してしまう。したがって，分子量の ある大きさのところで、 $\mathrm{CaCO}_{\mathrm{z}}$ 析出抑制能が最大になることが 期待されるのである。

CV 曲線および GP 曲線は, $\mathrm{pH}$ によって変化しないが,これ はつきのよらに説明される。PAA の $\mathrm{Ca}^{2+}$ イオンに対するキレー トカは、, $-\mathrm{COOH}$ 基の解離ととるに大きくなるが、これは-COO基が $\mathrm{Ca}^{2+}$ の眍位子として動くためである。解雄度は $\mathrm{pH} 8.0$ 位 までは $\mathrm{pH}$ の上昇ととるに增加するが， $\mathrm{pH} 8.0$ 以上では変わら ないので， CV 值 (および GP 值) が $\mathrm{pH} 8.5 \sim 9.5$ で変化し ないことを理解できる。

\subsection{AA·HAPS およひ AA·APDO}

AA·HAPS およひ AA·APDO コポリマーの分子量（ $M W=$ 3000）を一定とし, 官能基（AA, HAPS および APDO）のモル

4) $\left[\mathrm{Ca}^{2+}\right]=2.55 \times 10^{-3} \mathrm{~mol} \cdot \mathrm{dm}^{-3}$ で一定, $\left[\mathrm{CO}_{3}{ }^{2-}\right]_{\mathrm{T}}=5 \times$ $10^{-3} \mathrm{~mol} \cdot \mathrm{dm}^{-\mathrm{a}}$ であり, $\left[\mathrm{CO}_{3}{ }^{2-}\right]=\left[\mathrm{CO}_{3}{ }^{2-}\right]_{\mathrm{T}} \cdot K_{1} \cdot K_{2} /$ $\left(\left[\mathrm{H}^{+}\right]^{2}+K_{1}\left[\mathrm{H}^{+}\right]+K_{1} K_{2}\right)$ Kより $\left[\mathrm{CO}_{3}{ }^{2-}\right]$ を計算した。

5) H.P. Gregor, M. Frederick, J. Polym. Sci., 23, 451 (1957).

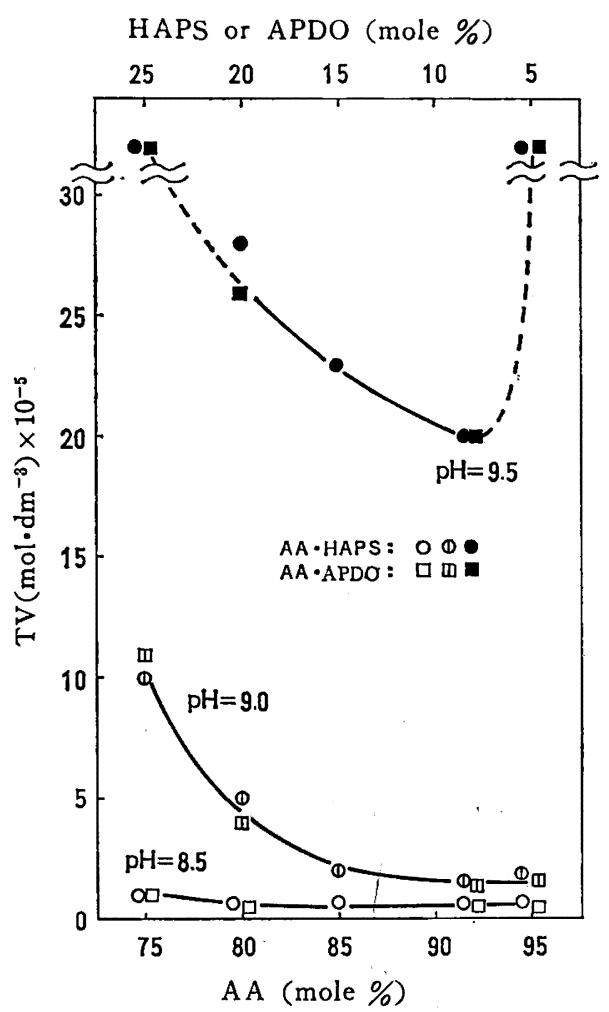

Fig. 3 Relationship between the mole percentage of $A A$ and the threshold value (TV) for AA.HAPS and $A A \cdot A P D O$

The initial concentrations of $\mathrm{Ca}^{2+}$ and $\mathrm{HCO}_{3}^{-}$were 2. $55 \times 10^{-3} \mathrm{~mol} \cdot \mathrm{dm}^{-3}$ and $5 \times 10^{-3} \mathrm{~mol} \cdot \mathrm{dm}^{-3}$

AA.HAPS and AA.APDO were added at different concentrations and the solutions were kept at $60^{\circ} \mathrm{C}$ for $20 \mathrm{~h}$

分率を変えて，種々の $\mathrm{pH}$ におけける.TV 值, $\mathrm{CV}$ 值および $\mathrm{GP}$ 值を調べ，その結果を図 3 抌よび 4 に示した。

TV 值（図 3）は, pH 8.5 の場合, 官能基のモル分率によって あまり変化しない（AA のモル分率が 75９5\% のとき $0.5 \times$ $\left.10^{-5} \sim 0.9 \times 10^{-5} \mathrm{~mol} \cdot \mathrm{dm}^{-8}\right)$ が, pH 9.0 の場合にはその值が全般 に大きく, かつモル分率の增大につれて減少している（AA 75～ 95 モル\%のとき, $\left.10 \times 10^{-5} \sim 1.5 \times 10^{-5} \mathrm{~mol} \cdot \mathrm{dm}^{-3}\right)$ 。 $\mathrm{pH} 9.5$ では $\mathrm{TV}$ 值はさらに大きく, 曲線に極小が現われる。これらの結果は つぎのよらに説明できる。

いずれの組成についても，CV 值（図 4 a) すなわちキレート 化能は, AA のモル分率の增加 (HAPS なた APDO のモル分 率の減少) につれて単調に大きくなってゆく。GP 值 (図 4 b) は AA のモル分率が $75 \sim 92$ モル\%では $30 \times 10^{-5} \mathrm{~mol} \cdot \mathrm{dm}^{-3}$ 以上 で, ゲル化はきわめて起こりにくいが，95\%になると急激に低下 してゲル化が起こりやすくなる。以上のように, 分子量固定の場 合，カルボキシル基の割合が增えるとキレート化能が增し，ゲル 化しやすくなることが明らかである。TV 值に極小（析出抑制能 の極大）の現われる理由は， $\mathrm{CV}$ 値と GP 值の競合のためであ ク，PAA の場合と闹じょらに説明される。 CV 曲線扰よび GP 曲線（図 4）には $\mathrm{pH}$ の影響がなく，TV曲線（図 3）では， $\mathrm{pH}$ とともに TV 值が大きくなるが，これらに対する説明も 


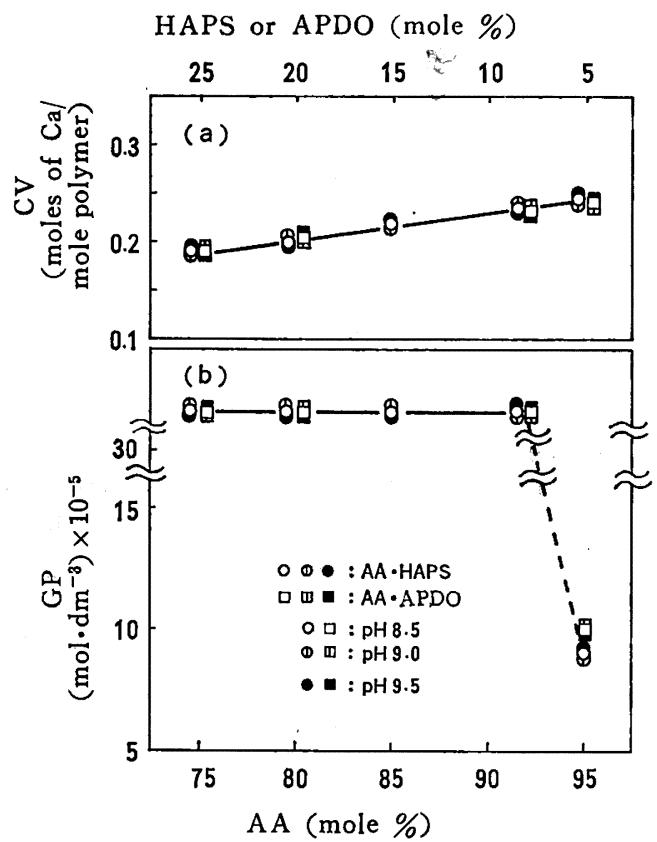

Fig. 4 Variations of the chelating value (CV) and gelation point (GP) with mole percentage of AA for AA.HAPS and AA.APDO

$\mathrm{CV}$; The initial concentrations of $\mathrm{Ca}^{2+}$ and polymer were $5 \times 10^{-3} \mathrm{~mol} \cdot \mathrm{dm}^{-3}$ and $5 \times 10^{-3} \mathrm{~mol} \cdot \mathrm{dm}^{-3}$ The solutions were kept at $30^{\circ} \mathrm{C}$ for $20 \mathrm{~h}$

GP ; The initial concentration of $\mathrm{Ca}^{2+}$ was $2.55 \times 10^{-3}$ $\mathrm{mol} \cdot \mathrm{dm}^{-3}$

The solutions were kept at $60^{\circ} \mathrm{C}$ for $20 \mathrm{~h}$ after adding polymers at different concentrations

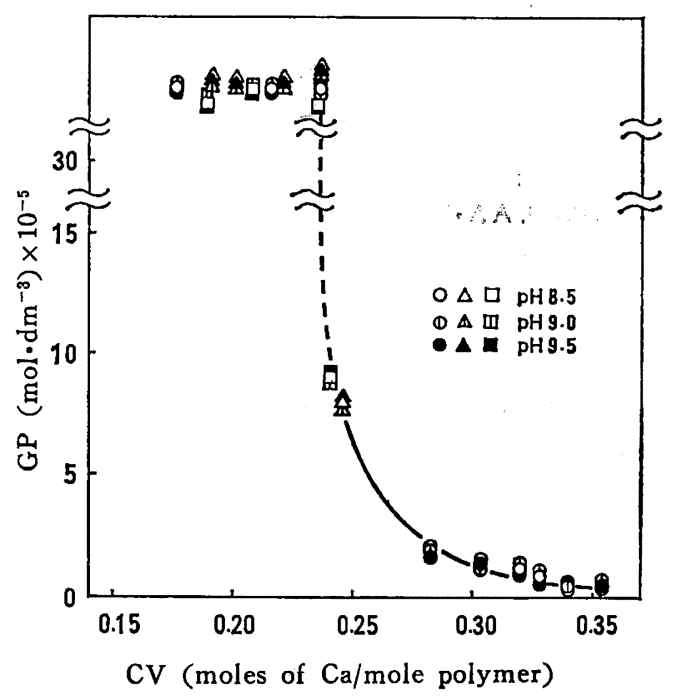

Fig. 5 Relationship between the chelating value (CV) and the gelation point (GP) for PAA (ODO), AA.HAPS $(\triangle \triangle \Delta)$, and AA.APDO ( $\square \square \square)$

\section{PAA の場合と同じと考兵られる。}

\subsection{CV-GP-TV の束一的関係}

以上に述べたように，ポリマーの TV 值 $\left(\mathrm{CaCO}_{8}\right.$ 析出抑制能) は, 分子量および組成にかかわらず CV 值 (キレート化能) およ

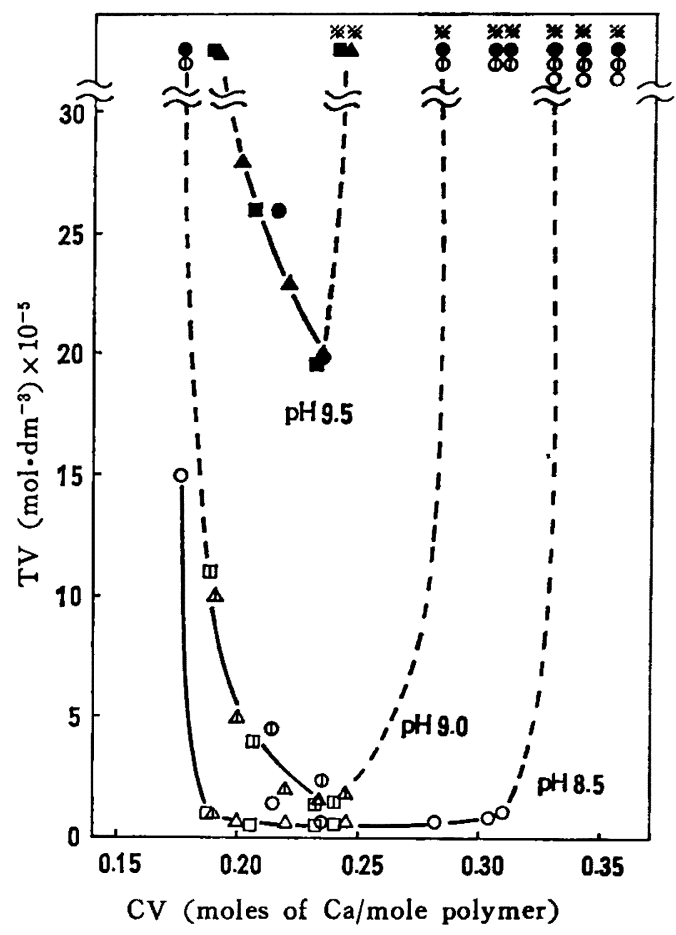

Fig. 6 Relationship between the chelating value (CV) and the threshold value (TV) for PAA (ODO),

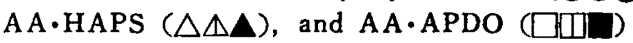

* Indicate the occurence of gelation

び GP 值（ゲル化しやすさ）の両者によって決定されることがわ かったが, この3者の間の関係をすら少し詳しく榆討するとつぎ のようになる。

まず使用したすべてのポリマーについて，CV と GP の関係は 図 5 の一つ曲線で与えられる。すなわち，ボリマーの種頉に関 係なく，その CV がある值を越えると急激にゲル化が起こること を示している。また，CV-TV の関係については，pH によって は変化するが, ポリマーの種類によっては変わらない一つの曲線 を示す（図 6)。したがって，pH さえ固定すれば，CV-TV-GP の3者はポリマーの種類によらない一つの束一的な関保にあると いえる。そして、このことから明らかなよらに，ある与えられた ポリマーについて CV 值さえわかれば，その全容を図 5 およひ 6 から簡単に理解することができるのである。

\section{4 ゲル化の機權}

ポリマーのゲル化には $\mathrm{Ca}^{2+}$ イオンが関係していることは前に も述べたが，その内容をもら少し明らかにするため，つぎの俟討 を行なった。四 7 は $\mathrm{Ca}^{2+}$ の添加瀑度を一定とした液に種々の ポリマーを添加し，その謴度を增加していったとき，ゲル生成に よる溶液の吸光度（濁度）の変化を示するのである。どのポリマ 一についてす，濁度（ゲルの量に比例）はポリマーの添加度と ともに增大するが，ある湿度を越えると逆に減少してゆき。ゲル は消隇してしまうの。これはつぎのよに説明できる。ポリマー

6) $\mathrm{PAA}-1$, PAA - 2, AA-HAPS -, AA-HAPS - 4, AA·HAPS-5, AA・APDO-3, および AA・APDO-4 はいずれるゲルを生成しなかったが、これはキレート化能 が小さいからである。 


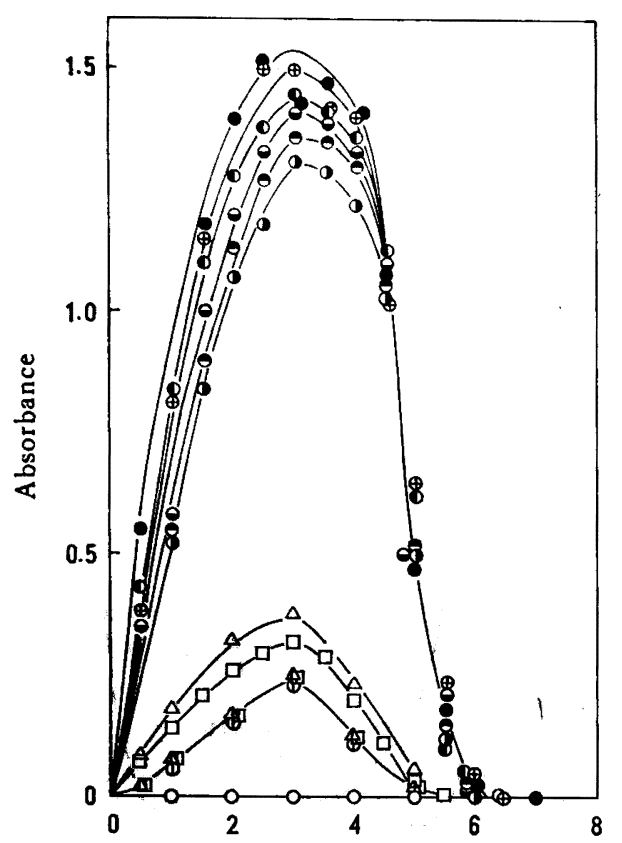

Concentration of polymer added $\left(\mathrm{mol} \cdot \mathrm{dm}^{-3}\right) \times 10^{-8}$.

Fig. 7 Relationship between the concentration of polymer added and absorbance of the solution

The initial concentration of $\mathrm{Ca}^{2+}$ ion was $2.55 \times 10^{-3}$ $\mathrm{mol} \cdot \mathrm{dm}^{-8}$

Gels were formed at $\mathrm{pH}=8.5$ and $60^{\circ} \mathrm{C}$ for $2 \mathrm{~h}$

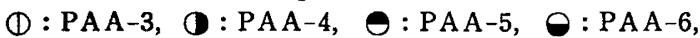
D : PAA $-7, \oplus:$ PAA-8, $:$ PAA $-9, \triangle:$ AA.HAPS -1 , $\triangle:$ AA $\cdot$ HAPS-2, $\square:$ AA $\cdot$ APDO- $1, \square: A A \cdot A P D O-2$, $\mathrm{O}: \mathrm{PAA}-1, \quad \mathrm{PAA}-2, \quad \mathrm{AA} \cdot \mathrm{HAPS}-3, \mathrm{AA} \cdot \mathrm{HAPS}-4$, AA-HAPS-5, AA·APDO-3, AA-APDO-4

の酸基は中性溶液中では完全解離しており，そのためポリマーは ひとつの陰イオンとして存在する。そしてこの陰イオンは $\mathrm{Ca}^{2+}$ イオンと

$$
\mathrm{Ca}^{2+}+2 \mathrm{RCOO}^{-} \longrightarrow \mathrm{Ca}(\mathrm{RCOO})_{2}{ }^{0}
$$

のようК反応してゼロ荷電の錯体を形成しこの錯体が凝集また はミセル形成を行なってゲル化するのであろら。与えられた $\mathrm{Ca}^{2+}$ 量のあとで，ポリマーを添加してゆけばそれに応してゲル 量は增大してゆくが，ポリマーの添加量が $\mathrm{Ca}^{2+}$ に対応する量を 越えるとゼ口荷電錯体をつくり得ず，マイナス荷電をるつ錯体の ままでとどまる。ポリマーの高濃度の条件ではゲルは消隇してし まうことになる。

つぎにゲルを沪別し，ゲルに含まれている $\mathrm{Ca}^{2+}$ 量と $\mathrm{COO}^{-}$量 を測定したところ，表2のようにすべてのポリマーのゲルについ て $\mathrm{Ca}^{2+} / \mathrm{COO}^{-}$のモル比は 1:2 になって拈り, 上に述べた推論 を確かめることができた。

ボリマーのスケール生成防止郕としての挙動は，図 7 において ポリマー漫度がきめて小さい原点の付近の結果によって説明す べきであり，この部分を払大して示すと四8のよらになる。すな わち、与えられた $\mathrm{Ca}^{2+}$ 浱度のもとで, ゲル化が始まるにはポリ マーに応じてある限界渡がある。これについてはすでに説明し たか，ポリマーの $\mathrm{Ca}^{2+}$ に対するキレートカが大きいはど限界濃

Table 2 Mole ratios of $\mathrm{Ca}^{2+}$ ions and $\mathrm{COO}^{-}$groups included in the formed gels

$$
\text { Code }
$$

PAA-4

PAA-5

PAA-6

PAA -7

PAA-8

PAA-9

A A $\cdot$ HAPS -1

$\mathrm{AA} \cdot \mathrm{APDO}-1$

The initial concentrations of $\mathrm{Ca}^{2+}$ ion and polymer in solution were $2.55 \times 10^{-3}$ and $3 \times 10^{-4} \mathrm{~mol} \cdot \mathrm{dm}^{-3}$.

Gels were formed at $\mathrm{pH}=8.5$ and $60^{\circ} \mathrm{C}$ for $2 \mathrm{~h}$.

Gel formation was not observed for the rest of polymers because of lower $\mathrm{CV}$ values.

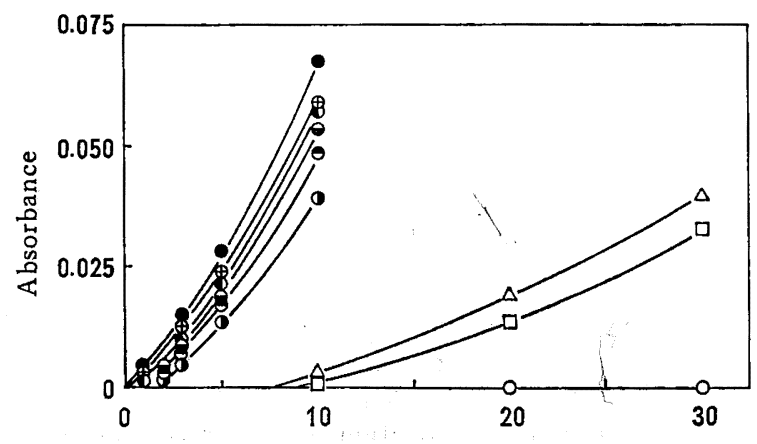

Concentration of polymer added $\left(\mathrm{mol} \cdot \mathrm{dm}^{-3}\right) \times 10^{-5}$

Fig. 8 Relationship between the concentration of polymer added and absorbance of the solution

The initial concentration of $\mathrm{Ca}^{2+}$ ion was $2.55 \times 10^{-3}$ $\mathrm{mol} \cdot \mathrm{dm}^{-3}$

Gels were formed at $\mathrm{pH}=8.5$ and $60^{\circ} \mathrm{C}$ for $2 \mathrm{~h}$

0 : PAA-4, $\odot: \mathrm{PAA}_{-5}$, $\bigcirc: \mathrm{PAA}-6$, $1: \mathrm{PAA}-7$, $\oplus:$ PAA-8, $\bigcirc$ : PAA-9, $\triangle:$ AA.HAPS $-1, \square:$ AA. APDO-1, O : PAA-1, PAA-2, PAA-3, AA-HAPS-2, A A $\cdot$ HAPS -3 , A A $\cdot$ HAPS -4 , A A $\cdot$ HAPS- 5 , A A APDO-2, $A A \cdot A P D O-3, A A \cdot A P D O-4$

度が小さくなる。いずれにしても，実際にポリマーを使用するさ いには，この限界濃度を越えないように注意する必要がある。以 上の検討結果から，ポリマーのゲル化機構についてはかなり明ら かになった。

\section{4 結 論}

高分子電解質（ポリマー）の分子量㧊よび組成を大幅に広げ， 種々の $\mathrm{pH}$ 条件において TV 値, CV 值および GP 值を判定し た結果, (1) ‘ポリマーの炭酸カルシウム析出抑制能はその $\mathrm{Ca}^{2+}$ キレート化能およびゲル化しやすさによってきまる'という前報 の結論を再確認するとともに，あらたに（2）CV-GP，および CV-TV 間には，ポリマーの種類に関係なく一義的な関係がある ことを見いだし（3）与えられたポリマーについて CV の測定 值から $\mathrm{CaCO}_{3}$ 析出抑制能を判定し, 適正添加条件を判定し得る ことを明らかにした。また（4）溶液の $\mathrm{pH}$ が增大するとポリマ 一の適正添加条件が狭くなり，かつ抑制能が減少することを示 
し、これが $\mathrm{CaCO}_{3}$ の過飽和度の增大によるとして説明した。さ らに, (5) ゲル化はポリマーの $\mathrm{COO}^{-}$基に $\mathrm{Ca}^{2+}$ イオンが吸着 してゼロ河電錆体を生じここれが凝集またはミセル化するためで あることを明らかにした。
おわりに，本稿をまとめるにあたり，御指迹や御討绕を睗わっ た北海道大学名誉教授永山政一氏に梁く留期致します。また，有 益なこ指道をいたたきました栗田工業株式会社総合研究所重后光 生氏に梁く感謝致します。

\title{
Effect of Molecular Weight and Chemical Composition of Polyelectrolyte on the Inhibition of Scale Deposition ${ }^{\dagger}$
}

\author{
Masaru Окамото* and Shiro HaYashi** \\ Kurita Central Laboratories, Kurita Water Industries Ltd.; Wakamiya, Morinosato, \\ Atsugi-shi 243-01 Japan \\ ** Present address: Research and Development Division, Kurita Water Industries Ltd.; \\ Nishi-shinjuku, Shinjuku-ku, Tokyo 160 Japan
}

The function of polyelectrolytes (polymers) to inhibit $\mathrm{CaCO}_{3}$ scale deposition explained in a previous paper was thoroughly examined using solutions with various $\mathrm{pHs}$ and a number of polymers with different molecular weights and chemical compositions.

Polymers used were nine polyacrylates (PAA) having molecular weight of $600 \sim 25000$, five acrylate/2-hydroxy-3-allyloxy-1-propanesulfonate copolymers (AA/HAPS) with molecular weight of 3000, and four acrylate/3-allyloxy-1,2-propanediol copolymers (AA/APDO) with molecular weight of 3000 .

As pointed out previously, the inhibiting ability of polymers increases with its chelation affinity to $\mathrm{Ca}^{2+}$ ion but decreases when the chelation affinity excessively increases to facilitate the gelation. The maximum inhibition was obtained in a certain intermediate range of molecular weight for PAA, and at a suitable AA mole fraction for AA/HAPS and AA/APDO copolymers. The inhibition efficiency decreases with an increase of solution $\mathrm{pH}$, probably because the degree of supersaturation of $\mathrm{CaCO}_{3}$ is higher with higher pHs. For all the polymers, a simple common relationship between the inhibiting ability of polymer for $\mathrm{CaCO}_{2}$ deposition and its chelation affinity is obtained.

For all the gels, it was found that $\mathrm{Ca}^{2+}$ ion is contained in the gels and the mole ratio of $\mathrm{Ca}^{2+}$ ion and $\mathrm{COO}^{-}$group is always $1 / 2$. This result indicates that the gelation results from the formation of zero-charge polymer complexes by the reaction with $\mathrm{Ca}^{2+}$ ion.

$\dagger$ Studies on the Prevention of Calcium Carbonate Scale Deposition by the Addition of Polyelectrolytes. II. 